\title{
TEMPORARINESS, VulnerabiLITY AND Transforma- TIONS IN SYRIAN FAMILY RELATIONS DUE TO FORCED MIGRATION
}

Sabine BaUer-Amin, Maria Six-Hohenbalken, Institute for Social Anthropology, Austrian Academy of Sciences

\section{ConTent}

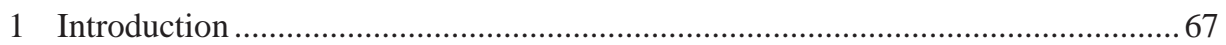

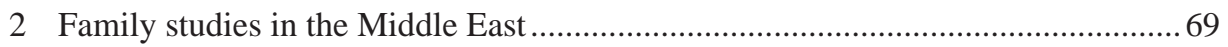

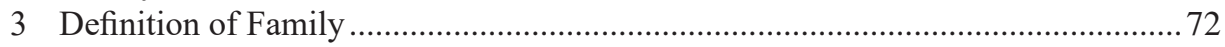

4 Legal Asylum Decisions and their Ramifications on Family Life .......................... 75

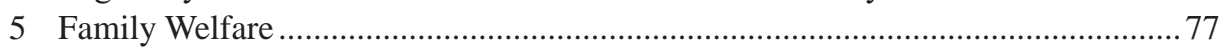

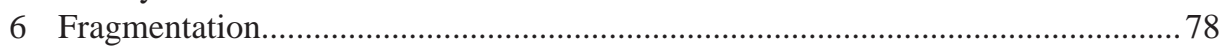

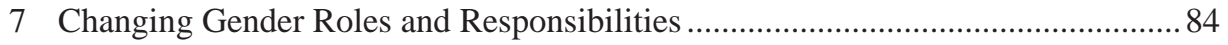

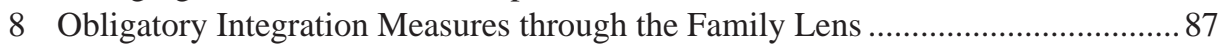

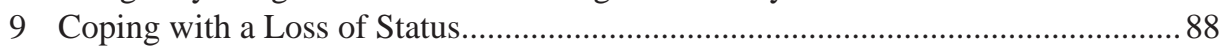

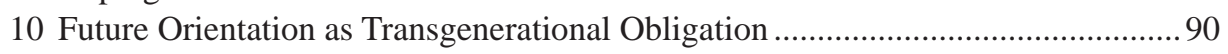

11 The Shaping of "The Refugee Family" by The State.............................................93

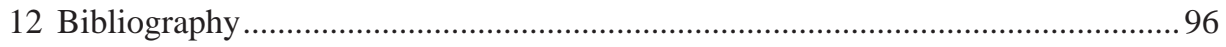

\section{Introduction}

"Wallahi, I have psychological pressures. It is true, I am here with my children, but the rest of my family is still under bombing. They were bombed yesterday, and they were picked up from under the rubble. I can show you the picture when they were picked up from under the rubble", 
Omayma said under tears, taking out her phone to show the WhatsApp pictures from her family in East-Ghouta, Syria. They revealed a destroyed house, broken pots, and humans wrapped in dust and blood. 48-year-old Omayma had left Syria in 2015 when her oldest son, who was conscripted to military service, was announced dead in a military prison. In order to spare her other adolescent sons the same fate, Omayma and her husband decided to leave for Europe and received asylum in Austria. Shortly after the family had left, they were informed that the eldest son was in fact still alive. Yet, they never received any notice about the son's whereabouts. "I am not able to focus ", Omayma continued while remembering her troubles in the obligatory German classes:

"There is something distracting me. Something is occupying my mind here. I have things working in my brain at the same time. I cannot focus. I forget very fast. No, not like this. I cannot forget my family! No! I cannot forget my first-born. In our Arab society, the first-born son: the mother cannot let him go...We came here. It is safe, there is no bombing, but we are still under psychological pressure. There is a war in our country."

While Omayma, her three younger children, and husband made their way to Austria and witnessed war from a distance, they were still very much affected by the events in Syria. Not only did the uncertainty of whether their beloved ones were alive or dead shape and dominate their everyday life but also the perpetuated feeling of loss and grief. Omayma expresses her suffering from afar, witnessing war and violence via WhatsApp and Facebook. She makes clear how these events deeply impact on her well-being. Do we do justice to the complex phenomenon of forced migration if we only look into the individual suffering? Singularising refugees out of context of their relations to family might obscure the view of the destructive effects of forced migration on families.

Suad JoSEPH, in her iconic work on the construction of the Self in Arab families, invites us to see individuals in Arab families as "embedded in relational matrices that shape their sense of self but do not deny them their distinctive initiative and agency" (1999, p. 11). Following JosePH, the self hence comes to the forefront through its relations within these matrices. Hence, this chapter explores effects of forced migration and the bureaucratic apparatus regulating refugees' lives on family structures and dynamics. It looks in particular into the fields of asylum law and 'integration' trajectory inscribed in the integration act in Austria.

Omayma was part of a research project at the University of Vienna and the Austrian Academy of Sciences, in which first experiences and expectations of refugees from Afghanistan, Iraq, and Syria were researched. Around 90 refugees, who had arrived in Austria in the past years, narrated their experiences on education, the labour market, representation, social connections and housing. All interviews were in the mother tongues and lasted between 1 and 4 hours. The project took place between April 2017 and October 2019, most of the interviews happened between mid-2017 and mid-2018. What became 
obvious was, how relations and responsibilities to family ran through all clusters of the interview. It became increasingly important to address this point in particular. ${ }^{1}$

This chapter brings together literature on forced migration and on family studies in the Middle East and contextualises it with the example of refugees from Syria in Austria. It hence fulfils a prognosis by Dawn CHATTY that there will be literature that looks into "the contemporary massive displacement of the Syrian Arab family as refugees and exiles” (CHATTy 2018, p. 234). Thereby, this chapter answers to an academic need diagnosed by Suad JoSEPH that "Scholarly research is needed to assess the impact of violent disruption on family structure and dynamics and chart possible avenues to remedy the conditions of these fractured families” (JOSEPH 2018a, p. 486).

Inherent in refugeeness are “'historically and temporally disjunct and ambivalent subjectivities' and what critical scholars of refugee issues call 'liminal spaces'...” (SHAKYA et al. 2014, p. 133). In this paper we aim to scrutinize the intersections in these liminal spaces, thus discussing questions of vulnerability in family refugee networks, precisely in focusing on fragmented and scattered families, transformations in family structures and coping mechanisms during transitional processes or protracted asylum procedures. The Syrian refugees with whom we have worked with have to deal with temporariness, which is caused by state policies and refuge regimes as well as the space-time relations of re/de-territorialization. The focus is beyond the decisive legal framework of nuclear family herein, but we will bring in the interlocutors' understanding of family and family relations as well as academic approaches to analyse family structures in an encompassing meaning.

We begin by giving a brief outline about family structures in the Arabic and Syrian realm and discuss transformations due to forced migration, such as changes in gender roles and shifts in the generational relationship. Herein we will analyse the new temporalities refugees have to face. Based on conceptual outlines of researching refugee families as a social unit, we will discuss vulnerability due to protracted liminal spaces of fragmented families. Finally, we will scrutinize the role of the residence countries in shaping family structures.

\section{Family studies in the Middle East}

The structuralist and functionalist approaches in social anthropology focused on the institution of the family in the Middle East as a core unit for analysing various societies in the Middle East. In comparison to the vast literature in the last decades of the $20^{\text {th }}$ century, during the last two decades family studies and transformations of family structures in the

1 A focus on the transformations of family structures would have required another methodological approach and a sensitivity on the intrafamily structures, as e.g. LiAmPUTTONG argues, "When researching a family, it involves more than one family member and a disclosure of one family member may violate the privacy of others” (2007, p. 27). 
Middle East have in general not been highly ranked on the research agenda. The transitions of family structures due to workers' migration was an important research topic in Turkey, however comparable studies where not that prominent in other MENA countries. The family centred approach was partly superseded by an increased focus on gender roles.

The Mediterraneanist approach of the 70s and 80s had focused largely on topics related to family, such as marriage patterns (e.g. BoISSEvaIN 1979), patronage systems (e.g. Davis 1977) or gender roles (e.g. Duvignaud 1970). In reaction to these older studies' essentializing tendency, a critical rehearsal of its approaches followed as well as a shift to a strong gender studies bias. Furthermore, studies in the Middle East mirrored partly national methodologies and increasingly focused on the effects of economically motivated migration movements in the last few decades, e.g. the huge efforts in studying transition processes of Turkish family structures. Comparative studies in social sciences that elaborate on the transformations of family structures in the Arab speaking countries were limited for a long time. The necessity for a fluid but vigorous network to discuss transformation processes and examples for transitory processes was e.g. shown by Hopkins based on the interdisciplinary Cairo Symposium on the "The New Arab Family" (2000). Comparative studies are realized by the study group on Arab families founded by Suad JOSEPH in 2001, based on the Cairo Symposium. This group of 17 scholars has produced a critical amount of literature through their individual projects on regional ethnographic and historical developments. Some NGOs and independent policy research centres have followed the turn, such as the 2004 funded Doha International Family Institute (DIFI). DIFI was founded to support the Doha declaration on the family and to broaden global knowledge on the Arab family. Most previous publications had touched upon family only through a focus on gender, labour or migration but not as a unit of analysis per se (AL JEHANI, Nour AL MALKI 2018, p. xi). The problem that many researchers on the family in the Middle East faced was that "mainstream gender analyses in the region largely conceived of 'family' in opposition to an individualized women subject struggling to assert her rights against family suppression” (JOHNSON \& JoSEPH 2009, p. 2). The dominant feminist approach often leads to an orientalist view casting women into victims and inferior positions in families that they had to escape from. In the resulting approaches, family hierarchies were examined with essentialised preconceptions rather than studied in their dynamic adaptation to shifting contexts in the middle East. Hence, the goal of the working groups on Arab family studies was to get "family and gender in dialogue" (JOHNSON \& JOSEPH 2009 , p. 2). Scholarship "cannot afford not to focus on family", JoSEPH (2018b, p. 1) critically remarks, as religion, national movements, gender or the formation of loyalties deeply impacts families and vice versa.

With violent events spreading over all of the region in the past years and in some cases, for example Palestine, for decades the effects of these events on families became a topic on its own, mainly covered by Penny Johnson (e.g. 2018), Julie PteEt (e.g. 1997) and Lisa TARAKA (e.g. 2006). With rising difficulties in stationary ethnographic fieldwork, a historical turn in family studies placed dynamics in historical contexts (KHATER 
2001; Doumani 2003; Pollard 2005; Lindner 2018). This history-focused literature investigates how family relations and dynamics have changed under processes of stateformation, colonial rule and economic transformations. Another influential topic in this "historical turn" could be that the institution of the family is often seen as a locus of tradition and of "good old times". In times of extreme uncertainty, researchers as well as political activists might be inclined to turn towards the past in finding again the familiarity of pre-war family life. Others deconstruct the nostalgic longing by proving that these golden years never existed, and family structures were constantly in transformation. Hence, war and armed conflicts do not only influence family dynamics but also the research produced about families as social institutions.

Scholarship on the Middle East has produced insightful literature on violent developments, militant events and war. Yet, JOHNSON and JOSEPH argue that despite the "historical and present social domination of war and mobilization of war" (JOHNSON \& JOSEPH 2009, p. 1), this stream of research has hardly interconnected the research on family studies. The urgency of looking into the disruptive effects of war on families is even more evident given the strong influence of these mobilisations on family structures, such as "the historical and present trajectories of labor and forced migration in a region characterized by the production of internal migrations, transnational families, and their forms of 'border crossings"” (JoHnSON \& JoSEPH 2009, p. 1).

Yet, there are, of course, some exceptions and initial works, as JOHNSON \& JOSEPH demonstrate in their edited volume on "War and Transnational Arab Families" (2009). For example, the demographic project called "Iraq Body Count" used household surveys to calculate missing bodies. It is estimated that from 750,000 up to one million Iraqi war widows were the direct consequence of the long-lasting wars and violence. An overview over various studies of the like is found by John TIRMAN's long-running "Iraq: The Human Cost project.” In his book "The Death of Others: The Fate of Civilians in America's Wars” (2011) TIRMAN writes about the Gulf War's impact on families. However, he does not address how family relations and formations also changed as a result of these wars. In Karin MLoDoch's (2015) study of Iraqi Kurdish widows, the tremendous effects on family structures and the whole society are shown. Women took over the role of the family head, had to struggle with insecurity, economic and psychological hardship, and faced social exclusion due to (neo)patriarchal understandings of families in post-war settings.

Diana AlLen (2014) describes life in the Palestinian refugee camp Shatila, Lebanon under "material and ideological crises" (2014, p. 2). Under failing national solidarities within the leadership in the camp, ALLEN showed, for example, how women faced an increased burden to fulfil the family and kin responsibilities. This led to a "retreat to neighbourly relations" and the creation of alternative networks as a "way of renegotiating the limits of family responsibility” (2014, p. 76).

Refugee Studies in Austria, however, focused on a variety of topics, such as motivations of flight, the situation on the home countries, experiences in the host countries, 
refugee regimes, and integration and home-making. All these topics are framed in, influenced by, and relevant to dynamics in families. Yet, despite its permanent presence, family has often been taken for granted rather than taken as the focus of an elaboration.

War, political and social upheaval, and tremendous economic and technological transformations have its impacts on the social institutions in the Middle East. As JOSEPH postulates, "In some cases, the capacities of families to offer oscillation, solidarity, protection, security, and emotional comfort have been depleted. In other cases, families are increasingly empowered as the singular trusted institution, despite inequalities or abuses they might transport” (JosePh 2018a, p. 485). Displacement and the fragmentation of families highly affects the functions and agency of a household (Young \& SHAmi 1997, p. 9). In addition, it shakes the experience and meaning of family to its core, affecting "family class positions, household heads' decision-making, marriage and family formation, familial political identities, and family economies in multiple sites” ( JOHNSON \& JOSEPH 2009, p. 2). With the breakdown of alternative support networks, family can become "the primary source of social security, economic security and often political security, especially in the context of weak and destabilized states and in the current conditions of war and violent upheaval in the region” (JOSEPH 2018b, p. 11).

Other than in the diaspora, ethnographic research on families in Syria since the outbreak of the war became almost impossible. The war led to the largest refugee crisis since the second world war. More than five million fled Syria. Many went to the neighbouring countries, like Turkey, Lebanon, Jordan, and Egypt. Six million are now internally displaced. Others tried to seek refuge in Europe; 45,000 Syrians have come to Austria since the beginning of the war (STATISTIK Austria 2020). Such huge mobilisations, fragmentations and transnationalisations have effects on social organization and family systems (JOSEPH, 2018b, p. 12).

\section{Definition of Family}

"Janna min gair nās matidās" ("Heaven without (your) people is not to be stepped in/worth it."). According to this Arab proverb, not even heaven would justify leaving family behind. Further, JoSEPH sees the institution of the family as a 'sacred space' (2000, p. 19 in Lокот 2012, p. 1). Interestingly, while in this proverb "people” is clearly understood as "the beloved ones" and mainly "family", the term used is "people”. This hints at the specific understanding of family that is not limited to the nuclear family but can include many more people. A brief closer look on the terminology gives an insight in the meaning of "family". In Arabic, bait (family, household), nas (people, folk), ahl (family, kin, kinfolk), usra (family, dynasty, clan) or 'á'ila (family, people, house), 'ašìra (clan, kinsfolk, ) or qurayīb (relative, family) can refer to various sizes of people, connected through a mutual sense of belonging and sameness, such as in NABER's research 
amongst Lebanese in Michigan, where the term "family" encompassed between 50 and 600 people (NABER 2009, pp. 149 f.).

This understanding of family is shaped by many other factors. GEBEL \& HeYNE (2017) released a comparative data analysis in the MENA Region, ${ }^{2}$ based on the World Value Survey (2014), the Arab Democracy Barometer, and further micro data to get an insight into family related understanding of roles and in the relationship between the family and the state. Important factors were questions of trust in state and civil society institutions, the influence of religion and the meaning of the family, besides further influential factors as education, economy, and the political system.

The study was formulated for the Ministry of Family Affairs in Germany and, therefore, a comparison with similar data in Germany was achieved. The results show that there is a difference in the relationship the individual has with their family. The "total" trust the single person has in their family is $12 \%$ lower in German families than the average in the MENA countries (especially in Egypt, Iraq and Tunisia trust in the family is highest (GeBel \& HeYNe 2017 p. 53)). The meaning of the family is rated as "very important" by $94 \%$ of respondents in the MENA regions, while the same holds true for $78 \%$ for German respondents.

Even this survey data shows the discrepancies in the meaning of family for the individual in the MENA Region and in Germany. With the exception of Syria, the data used for this analysis were organized before war and upheaval, so the statistics do not refer to the impacts of forced migration and the transformations of family relations herein. Neither can we assume that participants in the MENA region and in Germany had the same concept in mind when they were asked about "family".

The understanding of "family" that has developed in other regions of the world hardly captures "the dynamism of social systems in the Arab region, historically or in the present” (JoSEPH 2018b, p. 3; Young \& Shami 1997, p. 2). Theories based on Western histories and concepts mislead to scrutinize Arab family structures (JosEPH 2018a, p. 482). Using, for example, an understanding based on European or Austrian family developments specifically limits our capacity to comprehend "historical complexities in locale usage" (JosEPH 2018b, p. 3). The concept of family needs to be placed in historical and social contexts, in order to avoid "normativities" or assumptions that there are any "natural" or self-explaining definitions. This means that we cannot assume a "normal" family dynamic, a static unit, or explain what might be "dysfunctional" or claim a particular "type" of Arab family. As Loкот explains in her critique on the humanitarianist narrative - specifically for Syrian refugee contexts, that family structures depend on class, ethnicity, religion, rural or urban settings, "state feminism" and the influence of Islam, which has brought forth a variety of forms in space and time and a complexity in its transformations (see Lокот 2018, p. 2). She criticizes that this narrative discusses family structure issues on the basis of an assumption of "traditional” family structures,

2 MENA - Abbreviation for Middle East and North Africa. Data were available for Algeria, Egypt, Iraq, Jemen, Jordan, Libanon, Libya, Marokko, Pakistan, Palestine, Tunesia, Turkey and Syria. 
which does not recognize the variety of family relations and transformations before the war (see ibid. 2018, p. 2 f). Also inherent in the humanitarian narrative is the assumption that "social networks" of refugees collapse. LoKoT's research of self-settled Syrian refugees in Jordan shows how people try to uphold family ties and find both "strength and solace in family structures, as well as negative or mixed experiences of family ties" (2018, p. 6).

Amongst scholars working on the Middle East, three approaches to define family were dominant. Some scholars argue for investigating a common decent through bodily substances like blood (dam) or nerves $(a s \underline{a} \bar{b}) .{ }^{3}$ This would then include a vast number of possible people. Yet, this variety of people is often not meant when referring to "family", as it includes many other detrimental people such as affinal kin (YounG \& SHAmi 1997, p. 2). A second view investigates families as those who share a common household. This includes the unmarried relatives connected through blood/nerves but also those who married into the family. Often the household also includes employees. However, the household composition is not always stable. Sometimes members leave for an amount of time, i.e. women who stay in their mother's house after childbirth, labour migration, etc. (Young \& Shami 1997, p. 3). Due to violence and displacement, household compositions change rapidly and are more often the results of necessities or state-regulations. In contexts of forced migration, destructions of dwellings and the international dispersion of populations leading to separations of parents and children, siblings, and couples, to focus on households alone - even though they are increasingly seen deterritorialized and in transnational realms - would not depict the lived reality of refugee families.

Rather than reaching an understanding of family through the definition of size, consanguinity or affinity, a look into the functions of families in Arab countries is followed in the third approach. Often, family tasks must be accomplished by those who are comprised in a "family". Young \& SHAmi name as such, "[p]roduction, distribution, transmission, reproduction, and sharing a living space” (Young \& SHAmi 1997, p. 3). Families can be a support group amongst which collective action can be mobilized. Family bonds are moreover shaped by mutual responsibilities and a sense of connectedness. Yet, with the change of geographical distance between its members and the dispersion of a shared living space, also functions of a family change accordingly. Functions of families are deeply shaped by the demands of the contexts. Hence, living under war or as refugees transnationally or internally dispersed produces different necessary functions for a family than other everyday-life circumstances developed in previous studies.

Consequently, all three definition approaches seem incapable of catching the lived realty of families affected by war and forced migration, since the assumed "normalities" under which these definitions were developed are out of force.

In a more loose definition by JoSEPH, family is the "domestic sphere" that includes the "matrices of mothers, fathers, daughters and sons" but also "networks of siblings,

3 Used as an allusion to sperm. 
uncles, aunts, grandparents, cousins" and "socialization and education of children; marriage technologies, patterns, and changes; generational conflicts; familial decision-making; familial structures of power and authority; gender relationships; family migrations and movements; sexualities, reproduction, and their familial contexts; the production of masculinity and femininity; domestic servants and household labour; social theories about the family, children, youth" (JosePh, 2018b, p. 1). As such, it can be either a social institution, a social imaginary, statist project, discourse, trope of modernity, tradition, or multiple lived realities (JoHNSON \& JOSEPH 2009, p. 1). Such a broad definition seems to be more inclusive in capturing the complex phenomenon of war-affected families and can encompass the highly dynamic developments in which the impacts of the legal frameworks in host, transit, and in residence countries can be integrated respectively.

Based on our qualitative research methods and social anthropological approach we will give an insight to the meaning of family relations, its transformation and reinforcements. Decisive in the refugee context are the legal frameworks in which families have to organize themselves by and are confronted with during their refuge.

\section{Legal Asylum Decisions and their Ramifications on Family Life}

In Conventions and Acts of the UN regarding the rights of refugees, first released in 1951, the fundamental importance of family reunification for integration was stressed and, furthermore, the member states were invoked to handle the concept of family in flexible ways.

In 2003, twenty-five of the 28 EU Member States had ratified the EU Family Reunification Directive (UNHCR 2015). ${ }^{4}$ Chapter II of this Directive provides the definition of Family Members. The EU member states are obliged to apply the Directive's rules and fundamental rights regarding family life and the interests of children. According to this Directive, family members are the spouses of the sponsor, minor children, including adopted children. Minor children must be below the age of majority (set by the law of the Member State in concern) and must not be married. There are further categories which are subject to the "may" clause, thus the Member States can decide independently whether they include them in their concept of family and thus allow fam-

4 [European Union, Council Directive 2003/86/EC of 22 September 2003 on the right to family reunification, available at: $<$ http://eur-lex.europa.eu/LexUriServ/LexUriServ.do?uri=OJ:L:2003: 251:0012:0018:EN:PDF>; see also the outlines to and explanations of this Directive in PeERs \& ROGERS 2006. 
ily reunification. ${ }^{5}$ The EU Directive settles the family reunification for people who were granted asylum and those who have temporary protection. ${ }^{6}$

Family reunification has been a topic in European countries since the 1970s. The various immigration policies and regimes handled the question of family reunification (mainly in the realm of labour migration) differently (see e.g. KRALER et al. 2013; GriLlo 2008). Already in 2013, KRALER mentioned that, “... the Europeanisation of family migration policies not only established common (albeit weak) standards, but also initiated horizontal processes of policy diffusion, with governments adopting policies elaborated elsewhere in their own countries, most evident in the case of integration contracts and pre-entry tests" (2013, p. 22). For example, enormous differences developed within the Scandinavian countries; while Sweden has a more liberal policy towards family reunification, Denmark has applied a stricter regime (FoG OLwIG 2012). Herein tensions due to the divergence between family norms in transitions and concepts within migration law became apparent (see KRALER 2013, p. 23).

Despite UN Conventions and EU Directives, member states have possibilities to implement and interpret these laws and apply their concepts of family structure or realize their migration regime policies. These prescriptions and laws evoke renegotiation and reformulation of family ties and of kin relations and obligations. HEIDBRINK has analysed the strategies of care for unaccompanied minors and has discussed state practices in family reunification processes in the United States. She is "examining how the state (re)constitutes kinship ties for migrant children both within and beyond the confines of immigration detention" and analyses how state processes "known as "family reunification', structures migrant families, strengthening some relationships while negating others” (2014, p. 139). She criticizes the family reunification policies which do not "recognize other functional kinship arrangements such as same-sex couples, grandparent or childheaded households, single parent or polygamous households, godparents, or even extended kinship networks when members of that network are undocumented” (2014, p. 141).

Due to the different migration and asylum regimes in the various nation states, one has to scrutinize these state policy regimes/national backgrounds and to consider the transnational frames and implications.

Austrian law has a very narrow interpretation of UN prescriptions and the EU Directive of "Family Reunification". It is on behalf of the single EU member states to

$5 \quad$ First-degree relatives in the direct ascending line of the sponsor or his or her spouse, where they are dependent on them (...) adult unmarried children of the sponsor/spouse, where they are objectively unable to provide for their own needs (e.g. state of health), an unmarried partner, the sponsor is in a long-term relationship or registered partnership. „In the event of a polygamous marriage, where the sponsor already has a spouse living with him in the territory of a Member State, the Member State concerned shall not authorise the family reunification of a further spouse." Chapter V relates to unaccompanied minors and that the Member States shall authorise the family reunification of first-degree relatives in the direct ascending line, legal guardian or other member of the family in case relatives in the direct ascending line cannot be traced. (for the full text see UNHCR 2015, p. 2 f.).

$6 \quad$ See PeErs \& Rogers 2006, p. 231 and e.g. pp. 478 f. 
further include family members, besides the nuclear family, for allowing family reunification. $^{7}$

The Asylum Act 2005 defines a family member as either a "parent of an underage child, the spouse or the, at the time of filing the application, under-age single child" (ASYLG 2005, § 2 (1), 22). In addition to this rather tight definition that excludes children older than 18, and siblings or elderly dependants, the rules for family reunification are equally tight. Family reunification is only possible after having received a positive asylum decision. If the asylee applies for family reunification within the first three months after obtaining an asylum title, there are no further requirements. Most people, however, first need to save enough money to cover the costs of relocating their family and the required documents. Yet, if the three month period has passed, the family member in Austria has to provide enough income to support the family, a flat that would be big enough to host the family, and health insurance (ASYLG 2005, § 35, § 60). For many people, many years pass until they can fulfil these requirements. Those who have recieved subsidiary protection are required to wait even three years before veing entitled to apply for reunification. In addition, often a considerable amount of time, sometimes years, pass until they even receive their asylum decision.

\section{Family Welfare}

Despite the practice of protracted family reunification due to demanding legal requirements, scholars have pointed to the importance of family support. In fact, the disruption of families in the long run still needs further investigation. Longitudinal studies about the effects of refuge on the transformation of family structures is missing. Single studies have currently been analysing the effects of the migration regimes and state policies on refugees and the meaning of family structure and kinship solidarity in refuge contexts. EASTMOND shows the importance of family reunification for wellbeing and family welfare of Bosnian refugees in Sweden. "Many social networks had been disrupted by the war and, as a result, family and kin took on an even greater importance as the main source of trust and assistance in exile ... 'Family welfare' thus became a less-localised project, stretching across borders and including solidarity and exchange with family members in other places" (2012, p. 106 ff.). Mutual economic help and immaterial support can thus reduce the vulnerability caused by war and refuge.

A research team at the university of Illinois at Chicago (WeINE et al. 2004, 2005) has studied the processes, strategies, and lived experiences of Bosnian refugees in Chicago, who were engaged in multiple-family support. They scrutinized how families managed transitions and elaborated coping strategies for dealing with trauma and loss. WEINE et al. (2004) have stressed the meaning of family as the remaining social institu-

7 See PeErs \& Rogers 2006, pp. 600 ff. 
tion for Bosnian refugees and proposed a model labelled FAMCORT (FAMILY CONSEQuences of Refugee Trauma). This model was used for an applied project to organize and evaluate multiple-family group support and intervention projects.

FAMCORT focuses on four realms of family life and its changes namely, in family roles and obligations, in family memories and communications, in family relationships with other family members, and in family connections with the ethnic community and nation state (see WeINE 2014, p. 147). For each of these realms, the research team has analysed the strategies to cope with the consequences, called Families Rebuilding Lives, which is based on a mixed methods approach and a ground theory centred analysis.

Although our research design varied from the FAMCORT study ${ }^{8}$ and the preconditions are different, as the families in our cases are still scattered and waiting for reunification, there are various parallels in the transformation processes. We will thus elaborate on the meaning of fragmentation, the changing of the roles and responsibilities of the family members, the relation to the state in discussing the obligatory state integration measures through family lenses, and the memories of their former lives and coping with loss of status. Finally, we will elaborate on future orientations and transgenerational relations.

\section{Fragmentation}

Many families have hence been separated for long periods of time in different countries that vary greatly in their contexts. In cases of protracted refugee situations, particularly women and children stay behind either in their home countries or in camps and often have to wait for many years in limbo, thus waiting for family reunification until they join their husbands and fathers. Some family members remain in refugee camps in neighbouring countries, while others vanguard in gaining asylum in European countries and organize the family reunification. Women and children who stay behind, who are no longer integrated into a family network, makes them especially vulnerable. Several studies have pinpointed the gender related challenges in refugee camps, when single mothers have to head the households in the context of limited resources, the scarce opportunities to find employment, and the institutionalized multi-systemic violence for Syrian refugee women in transit countries such as e.g. Lebanon (Rola \& MoughaLian 2016, p. 27). A UNHCR research project among Syrian women in Egypt shows that women struggle with these new roles, as “... female heads of households face a higher risk of depression and psychological distress” (UNHCR 2014). Female refugees without a kin network thus often face sexual or gender-based violence. Researchers pinpoint gender-related sexual violence to both in the home country, where sexual violence was

8 Narrative interviews using a semi-structured questionnaire with Syrians of different ethnic, religious, economic and educational backgrounds; while the FAMCORT project applied a mixedmethods approach and a long-term study of Bosnians in an institutional setting. 
used as a weapon even in the first years of war, as well as in refugee camps or during the flight (see e.g. GüçER et al. 2013). The financial pressure, together with insecurity, may cause early marriages in order to prevent sexual harassment and gender-based violence (IRC 2012, 2014). Studies have pointed out that the marriage age of young women in insecure refugee settings has tremendously decreased in comparison to the pre-war marriage age ${ }^{9}$ in Syria (VAele et al. 2020, pp. 35 ff.; CHAKraborty 2019).

Sending women and children ahead was seen also as a strategy, as they might be perceived to be more vulnerable ${ }^{10}$ within the target countries, gain asylum easier, and their husbands would rejoin the family members afterwards (FrEEMAN et al. 2017, pp. 126, 137). Thus, there are several scenarios in the decision-making processes of families, in the case not all the members could organize the refuge at once. The consciously accepted fragmentation, whereby either the male or female members or the children were to be sent first and thus given the task to organize the family reunification, was decided, in order to minimise risk, upon the pressure in the countries of origin and transit countries as well as the opportunities available in the prospective target countries. In weighing the question of vulnerability, regardless of whether women and children stayed put or took the risk of a highly dangerous journey across the Mediterranean, the extended family network gained a huge impact. Researchers in Turkey argue that single women or single mothers with children who decide to risk the journey to Europe without any other support is a decision made only when they would have absolutely no other choice (FrEEMAN et al. 2017, p. 127). Researchers therefore speak of a gendered migration-violence nexus (ibid, p. 128). In addition, seeing refuge only as the decision of an individual overshadows the many processes and (family) dynamics involved that influence whether one stays or leaves.

Saber, 34 from Aleppo, came to Austria in 2014, leaving his wife and little children behind in Aleppo. Saber had left against his will.

"I did not want to come to the EU. I wanted to stay in Syria and fight Assad. I wanted to stay. I did not want to go even to Turkey. We have some business against Assad. From earlier times, forty years ago we already had problems with Assad. And my father said, 'Saber, don't stay here! Go to Turkey',', he explained.

Yet, once he reached Austria he applied for asylum, of which he was granted 1.5 years later. Afterwards, he tried to bring his wife and children but did not understand the legal necessities.

"I have, ... tried 100 times to bring my family from Syria. But I did not know my rights. Who [could help me]? With whom can I talk about it? It does not work."

\footnotetext{
9 It was shown that " 41 percent of Syrian girls in Lebanon were married before the age of 18", while - before the war in Syria - the rate of girls married after 18 was $13 \%$. CHAKRABORTY further explains that target countries in Europe refuse to accept "child marriages" (thus after 18) for family reunification, as the laws do not apply to them as many marriages were not registered properly (CHAKRABORTY 2019, p. 20 f.).

10 In this assumption of vulnerability, the agency of women is overlooked and "there is still a real lack of any kind of understanding of what this vulnerability means to different women, across boundaries of class, nationality, age, race, sexual orientation etc.” (FrEeman et al. 2017, p. 137).
} 
While Saber ended up in Austria against his own will, albeit following his father's wishes, he has since been trying to get his family to safety. His own delayed asylum procedure and the lack of knowledge about the reunification process fatally cost the family too much time, as the war in Syria continued.

"Because 2015, eh 2014, from August, until 2017 there were bombs in Aleppo every day. And stress. And then there was this with my family and then everything -. Then in 2015, I learned that my family was murdered through a rocket. There was no chance anymore. I wanted to go back to Syria. I have tried so often to have contact ... For more than three, four months ... [sigh] Then, one of my friends told me ... I asked my parents and they confirmed. I wanted to return immediately. But my father said if I return, I will not be his son any longer. I am his only son. And we have in Aleppo, in Syria, an Arab culture, that if I am the only one."

Saber's witness of war from afar, as well as his loss and inability to act upon it, had severe effects on his future orientation and well-being. Saber found himself repeatedly deliberating about returning to Syria and fighting Assad or staying in Austria and following his father's instructions. He recounted one of his hearings in his asylum procedure.

"So once, I met a judge. And I had a translator with me and I told him, "please say quickly, I want to go back to Syria and take a weapon with me and I do not want to stay in the EU. Just give me my passport and I want to go back. And fight Assad. And I don't want to stay in Austria. Just that. Please say that in German.' And he said, 'Saber, are you crazy? What is this?' And I said, 'Say it, say I am with Assad. Say I am a dictator, say whatever, I am military. I don't want to stay. Enough. 'And my father begged me to not return to Syria ... First, they were in Syria. But when the problems came, they left to Saudi-Arabia ..."

During the four hour interview with him and the many phone calls afterwards, it became clear that Saber was suffering to the point where day-to-day activities were impossible. His family's death and his inability to prevent it overshadowed his daily life in Austria.

"Maybe if Assad is away and murdered or so, I will go to the streets and dance. Maybe I will dance naked. Please, only Assad. That creates big problems, big stress for me. Also here in Austria, if I see someone who supports Assad, I get stressed immediately. Crazy. He killed my family. Not just my family, all these Syrians are murdered by him. And then I see a refugee in Austria who supports Assad! Please! Please go to Assad then. Assad is there. Stay there with Assad."

This passage shows how difficult it is to establish trust in the residence country and among Syrians in diasporic settings. In addition to his mental suffering, he has mistrust in his relations with co-ethnics and the only persons he feels close to are his family members who remain far away.

Being aware that he was not able to handle his grief on his own anymore, Saber sought help from a doctor. He narrated an incident when he went to see a psychiatrist 
who prescribed him psychopharmaceutic medication. Yet, because he did not trust the effects, he did not take it.

"And she gave me a pill. Sure, I threw the pill away, on the table. I have not taken it. I asked her if I could become addicted to it. She said, 'no, no, you will stay calm and be able to sleep.' Then I searched for it and read about it. I did not understand well. I read but I did not understand all. But for my brain this pill does not work. Then I threw it away. [laughs]. I do not want that."

Saber was not able to find sleep anymore, which deeply impacted his success in acquiring a new language or finding a job. When asking him how he spent his sleepless nights, he explained,

"I am in the internet, YouTube, Facebook,... Addiction for social media. My group, yes, so. And the time flies. Just this."

This quote also shows that a method considered conventional practice in Austria i.e. using medication to treat his psychological distress, was not reasonable for him. As he had no prospects, he could not show the necessary compliance, such as confidence in a medical treatment, which shows its effects not immediately.

Through Facebook, he was able to stay in contact with his sister in Turkey but also his parents in Saudi-Arabia. Although the Middle East had for years been shaped by labour migration, in particular the Persian Gulf, the effect of the war in Syria mixed the previous fragmentation with forced migration, creating even more dispersed transnational families. For many of them, social media became a daily companion in order to stay connected. "Facebook has become critical to transnational families. Should the internet be closed down or censored, those families that are now so vividly connected to each other across thousands of miles would be cut off.[...]" (JoSEPH 2018a, p. 489). Hence, the new connectedness via the internet binds transnational families differently than previous generations of (forced) migrants. JoSEPH explains, "[t]hey have ethnographically rich details of each other's lives and a sense of intimacy at a distance not conceivable for previous generations of immigrants. Pictures and video clips of weddings, vacation trips, eating out, swimming at beaches, and family outings circulate on Facebook, giving not only family members and unrelated networks - and researchers more access than could ever have been imagined even fifteen years ago" (JOSEPH 2018a, p. 489). This virtual intimacy and feelings of closeness seems to counteract the feelings of mistrust and loneliness, producing new forms of social life which fosters wellbeing and sociability for the individual.

BALDASSAR et al. have discussed the meaning of Information and Communication (ICTs) based technologies for transnational families and for the transformations of sociality. ICTs produce a kind of co-presence despite being separated by distance and time, strengthen ties, and circulate (economic, emotional, cultural social) sources (2016, p. 134). They argue that connectivity brings the mundane into a sharper focus and provides a transnational everyday reality based on ubiquity, simultaneity, and immediacy of interactions over borders (ibid, p. 136). In refugee contexts, a sustained co-presence 
seems much more difficult than in migratory settings, where realistic opportunities for family members to reunite are hardly realizable. They argue that family imaginaries and a sense of togetherness are produced when a get together is impossible (ibid, p. $139 \mathrm{f}$.).

Especially with the Syrian families fragmented due to war in recent years, we cannot assess the long lasting effects of ICTs, but our empirical material shows ambivalent effects. On the one hand, it reflects the encompassing meaning of ICTs for the wellbeing of the individual and for the re-creation of closeness and togetherness what people have lost in their real lives. On the other hand, people are not only informed constantly about the political developments and the war, but also about the suffering of family members who remained in the home country or are in a transit country. The almost simultaneous information about their critical states, about the death of beloved ones increases the vulnerability and psychological stress in exile.

Similar to the above, Omayma was in constant contact with her dispersed transnational family online:

"I talk more with the family that is in Syria. I also have a niece in Libya. Another one is in Britain. We talk more with them than with the rest. Just because we are closer to them than to the ones in Germany. Closer, closer on a personal scale. My niece is in Britain, my other niece is in Libya and we are here. And there is my uncle in Damascus. All of the family is almost entirely in Damascus, in Syria. Therefore, we talk more with those in Damascus."

While there has never been such high population mobility and disconnection in Syria than in recent years, through the possibility of connecting online many families are able to stay strongly connected. Yet, these new possibilities are different from the social closeness that many people, including Omayma, were used to before the war (JoSEPH, 2018a, p. 490). Drawing a map with items on the desk during the interview and setting them in close proximity to each other, she described,

"[s]o, I am here and my family is there and my sister is there and my brother is there. We are not used to the distance. We Arabs always immediately get together. We want to stay in the same neighbourhood, the same street, you know? For me, here we are all in different neighbourhoods but with my family we were all in the same neighbourhood. Arabs with each other. We do not like to take the bus or the tram or anything. Just to walk to be together. ... All the relatives are staying together. My family is here, my in-laws next to me, my uncles and aunts and their children, we all live in the same neighbourhood. Not that everyone lives in a different neighbourhood. I wish that now it would be at least like this. But now, we are in different countries. A part in Germany, a part in Britain, wallahi al-'azim in all countries. A part in Libya, and we are here and they are in Syria. It had us dispersed in all different countries. This is what makes it very very hard for us."

For Omayma, the fragmentation of her family was a strong source of distress;

"Yes, wallahi, I feel lonely and I feel depressed. Of course, I told you, I was used to have my family around a lot. My visits here are very limited. Until now, I am not 
emotionally at ease. And depression I feel as well. I don't know if my son or my family is okay. I feel depression and psychological pressures... Here, I don't have anyone. We are not together here."

When asking if her conversations with her dispersed family or the presence of her husband and three younger children were of support to her she answered,

"[e]veryone is in their own condition. All these people that I know have very similar conditions to ours. We all left our families. We all went on the way. And all of us, our financial situation is not great. Our conditional situation is still very constricted. Because everyone is in the same state. Yes, same state."

Yet, in other research, the state of witnessing war from a far is seen as a point of crystallisation of family networks. Nadin NABER explains that during the war on Lebanon in 2006, many Lebanese living in Michigan displayed their national flags proudly. She claims, "[c]ollective experiences with war from a distance brought people together in a communal state of emergency in which two questions took center stage: Has our village been attacked? Are our loved ones alive or dead?" (NABER 2009, p. 146). She argues that the siege of Lebanon led to configurate the family as an inclusive 'Arab family'. As such, she understands it as a broad community based on the shared experience of witnessing the state of siege in Lebanon from afar, which finally also included other Arabs, who had witnessed war and siege in countries to which they expressed belonging. Similarly to Omayma, the families also in NABER's study mainly intensified their relationship with family members in their homeland. Yet, in NABER's research, the war simultaneously caused a reconceptualization of belonging to those residing in America. "The invasion's violation of the domain of extended family, coupled with the tacit knowledge that (in the words of a local journalist and community leader), 'everyone had some family member impacted by the war,' inspired mobilization of the concept of family within the domain of the nation. The concept of family was crucial in galvanizing the sense of Lebanese unity that swept Dearborn.” (NABER 2009, p. 153).

The empirical examples have shown that there are new space-time relations and complex ties in these states of liminalities and transnational networks. These multiplexities of relations can evoke reinventions of kin relations, which might be supportive on the one hand, but might cause tensions and unaccomplishable obligations. Specifically in this protracted temporariness or in the states of limbo due to asylum regimes and legal frameworks, the vulnerability of families remains high and people are forced to rely on their own remaining social networks and to confirm and strengthen their kin networks, in which the transnationally scattered extended families seem to receive new importance. Following the initial loose definition of family that constantly changes its formation, meaning, and function, NABER's and Omayma's examples show how war and crises inherently reshape the meaning of family and the networks of closeness and belonging. JOSEPH, in addition, came to a similar conclusion. She followed five Lebanese families since 1994 who had migrated to the US and Canada. What JosEPH observed can also be traced, at least partially, in Omeyma's recollection of her family communication. The 
families that Joseph accompanied formed different familial networks. Under different conditions, these networks crystallized into various relational formations.

Lокот shows that "relational ties among Syrians are not static, but may both expand and shrink based on gender, age, reasons for friendship, attitudes towards outsiders and even geography of origin and host communities”. Here, grounded research is necessary, which analyses the refugees' lives before and after the period of refuge to avoid a generalization and to show the complexity and unpredictability of transformations in family structures (Lокот 2018, p. 16).

\section{Changing Gender Roles and Responsibilities}

These new relational formations were also witnessed by 51-year-old Radwa from Aleppo. When her sister decided to leave with her son and husband, Radwa took the chance to also take her adult children away from the war. After she had received her asylum decision in Austria and found a place to stay with her sons, sister, nephew, and brother-in-law, Radwa tried to bring her husband through family reunification but faced legal challenges.

"I went a while ago to the Red Cross to ask about the reunification with my husband, because I want to apply again for the reunification, and they refused. They told me that I'm here for 3 years, and the period to do the reunification is over. Then I told them that my daughter want her father and she can do the reunification instead of me, they refused also. They told me, that I have to work and to have a $€ 1,300$ monthly salary, then I can do the reunification for my husband...Even though finding a flat is hard, but finding work is harder and more important for me right now than finding a flat. [You need to earn] $€ 1,300$ per month ... I told the employee that my son is working. Can he bring his father? And she answered me: "no you have to work.",

Radwa's closest friend, whom she brought with her to support her during the interview, added,

"Reunification is a problem for us all. They ask for a lot of conditions. And everyone of us needs his or her family around. Everyone need his father or his mother, and his people around."

The current asylum law and its ramifications on the definitions on family as well as the conditions for reunification shaped the gender roles in Radwa's family. With her husband being absent and depending on Radwa's ability to find employment, Radwa became the head of the household.

"When I was in Syria, my husband used to take responsibly of everything. I just went to my job, cooked and that was it. I find difficulties in this thing." 
One of these new responsibilities as a household head was to rationalize the scarce amount of money that the family had in addition to saving for her husband's reunification.

"Right now, I have to buy the things on my own. My husband used to take the car and buy us things. But now I'm doing everything on my own. And I'm taking the responsibly alone ... I want to let my sons help me, and to let them buy the stuffs, but when they go, they buy us things that we don't need, and they spend a lot of money. And as you know we get a fixed amount of money and I can't spend more than it... This is why I should go: to save money and control our finance situation ... I have to save the money, so it will be enough until the end of the month."

In Radwa's case, the question of sponsorship for family reunification was striking. As she herself was not able to fulfil the necessary requirements, such as the monthly salary, she did not understand why another family member, e.g. her son, was not entitled to ask for family reunification. Legally, only the spouse can act as the applicant or parents for minor children. Families as social institutions who share responsibilities and economic resources are not considered at all in these legal prescriptions. Especially in Radwa's case, being a single mother with childcare obligations and at the age of over 50 , it is hardly realizable to fulfil the state requirements. In Austria in general, people aged over 40 are considered difficult to place in the job market. For refugees belonging to this age group and without further resources (support, education and work credentials, etc.) these legal prescriptions are not largely accomplishable. So, for refugees of the age group above 50, a chance to get legal employment is difficult to obtain. Required language skills, the recognition of work experience and/or diplomas are besides the agerelated concerned insurmountable obstacles.

People are condemned to inactivity which has its effects on cohabitation. When task divisions change rapidly, this has in turn an effect on the mutual living situation. Omayma's husband Radi used to work as a carpenter in Syria while his wife stayed at home and cared for the children. Coming to Austria, he was required to go through German classes before being allowed to work. For 53-year-old Radi, who already had difficulties in reading and writing in Arabic and no knowledge of the Latin script, the required German level felt almost out of sight.

"All of us want to work, but the government does not accommodate that. There are carpenters, there are blacksmiths, electricians, plumbers. There is everything ... They would already be working without these minimum language requirements. Instead of spending money on these as refugees, you should allow them to work. If they would let me speak to the president here, I would tell him the same thing. They should allow these people to work. These people cost the Austrian state money and it would be better if they would work and sustain themselves. But you do not allow them to work because of the Ausbildung thing. They would be adding to the Austrian economy and not costing it. I do not know how much the refugees are costing the Austrian state." 
Radi, who had been responsible for providing for his family all his life, was struggling with his now newly enforced education and the time he had to spend with Omayma in the house.

"If I stay at home, this just causes problems between me and my wife. It creates grounds for fighting all the time. It is a lot of grounds for fighting. I have a lot of times on my hands and I am staying home. I would prefer if I was working. I know a lot of people who are divorcing each other because they are staying with each other all the time. This problem happens to a lot of Arabs here. This non-workingthing is affecting the relationships ... It affects people, even sub-consciously. The problem is that both, husband and wife, are just staying and doing nothing. They are just staying there in their houses or the camps. He is not working, she is not working. And they are just sitting around. And they start picking on each other. If I had a job, I would leave in the morning and come in the evening and my wife could not pick on me. When I would come home, my wife would have cooked something for us. She would have managed this meanwhile. I would come home and she would be happy and tell me 'hallo, hallo'. But if we both stay at home and look at each other the whole day, this is just grounds for fighting. All we talk about is 'I sleep here and you sleep there'. This is how it is at the moment ... We are safe, we have a house. What we really need is to have work ... If it continues like this, we run into problems. For what? Me and my wife are married since 1991, 26 years now or 27 years. We never really had big fights. Now, since we are here, we are fighting. It is because we are facing each other all the time. We have a lot of free time on our hands. She now tells me, 'Go away from my face, I do not want to see you anymore'. And she sends me away like this."

Previous research has already pointed to the emergence of martial tensions in times of war. Nadje AL-ALI writes that in Iraq spousal tensions led to a rise in divorcerates. Sanctions and war changed the patterns of social and family life, so that women, for example, no longer visited relatives in order to avoid embarrassment because of not being able to provide food for visitors (2005, p. 748).

The two interview quotes have shown that the change in gender roles evokes tensions and disputes within the families and causes further insecurity and distress. In the second case, an age-related issue in addition comes into effect. People who would be of working age have to face inaction. Especially for men this may compound the challenges in changing gender roles within the nuclear family and their status in the extended family. These legal prescriptions and socioeconomic hurdles reinforce psychological stress and vulnerability (see subchapter on de-qualification).

Especially from the children's perspective, the mediation and response of parents to displacement is of huge importance, as it can contribute to minimising risks and protecting mental health. VAELE et al. (2020) have pointed out that little is known of the parental roles, specifically the role of the father. In a research project among Syrian refugees in Lebanon (2016) the vulnerability of refugee families is shown, firstly due 
to economic reasons. $95 \%$ of the studied households relied on financial support from outside, predominantly on borrowing money and UNHCR funds, to cover their daily needs (living, food, healthcare). Joblessness and low prospects were considered to cause anxiety, anger, and frustration, which had its impacts on family lives and orientations. It was the intention of the research team to pinpoint the role of the fathers and provide psychosocial support to reduce distress and avoid hasty and irretrievable solutions for the children's futures.

Roles and responsibilities so far taken over by extended family have changed as well. One of these roles and responsibilities for example is marital mediation. For many, such extended-kin-interference was a familiar coping mechanism. For example, Radi, who often had his fights with Omayma, recounted,

"[w] hen we had problems back home, there was always family who intervened. Now, we have only each other. Now, I became very thick-skinned with her ... She cannot divorce me but she can tell me to leave and go away. And this is what she does all the time".

\section{Obligatory Integration Measures through the Family Lens}

After obtaining an asylum title, refugees in Austria are legally obliged to "integrate". The meaning of this is stated in Austrian integration law. The Integration Act of $2017, \S 2$ (1) defines integration as the process in which all immigrants actively participate in the measures of integration offered to them. In $\S 2$ (2), they further suggest a linear trajectory of these measures into integration. "Of key importance in this regard is participation through gainful work, access to and acceptance of education offers, equal treatment of the sexes, and the rapid achievement of the ability to earn one's living” (INTG 2017 §2 (2)).

The effectiveness of the proposed trajectory is ensured by conditioning social benefits upon compliance. Inherent to this understanding is the duty of the individual towards the state who then, in turn, would fulfil its humanitarian care responsibilities towards the individual. What is not included in these legal considerations is that forced migrants, like other non-refugees, hardly make decisions in detached from others. Next to enormous pressures under which forced migrants take the path of "integration": witnessing war from afar, coping with loss and grief, and trying to stay functional despite legal uncertainty; they are also affected by expectations and obligations of kin. This is reflected in necessities and priorities different to those of lawmakers and NGO workers. Omayma and Radi were very supportive of their children's efforts in language acquisition and education, as was also suggested to them through various state and non-state agents. However, Omayma and Radi saw Austrian integration-education for refugees 
at their age as a waste of time; time that Radi could invest in working and earning to secure the family's living. As shown in the initial quote, Omayma is still bewildered about the whereabouts of her first son, whether he is alive or not. So the couple has to deal with the past (with their traumatic experiences and the unclear destiny of their son), the present (the obliged and hardly realizable integration measurements, enforced inactivity and insecure financial state) and the future (the children's education and the upholding of the transnational family ties) simultaneously. Tize has shown in her study of families with tolerated status in Berlin, that due to legal insecurity children have to constantly reinterpret and reshape the experiences of resettlement (see TIzE 2020, p. 2). On the basis of multigenerational families who have been granted asylum, further research is needed to scrutinize the transgenerational effects of the protracted insecurity due to family fragmentation.

While all areas indicated by the integration act are influenced by family contexts, they also reflect on the functions, compositions and meanings of "family" for refugees in Austria. Two of the consequences are the coping with loss of status through a prioritisation of the children's future as well as planning for the future based on moral obligations towards the coming generation.

\section{Coping with a Loss of Status}

In addition to the many human and material losses that many forced migrants had to face, immaterial losses were often also unavoidable. These immaterial losses were bound to the lifetime achievements and social status that many had to leave behind. Both achievements and status were often not only based on individual's efforts but additionally on the collective work of many family members, sometimes over generations. Leaving the legacy of older generations behind and not being able to preserve it for the coming generation was often a painful experience. This experience included a transformation of social status and class, which reflects on subjectivities and the ability to find one's place in society. This experience of status transformation, often described as "shameful" towards society but also towards one's family near and far, was for many unbearable.

67-year-old Elise, from an aristocratic Damascene background, repeatedly took out her phone during our interview to show pictures of her large apartment in an upperclass Damascene neighbourhood as well as the two countryside mansions that she and her husband had inherited. While showing the pictures, she slowly went with her fingers over the paintings in them, the wood of the then new-doors, and finally an old chair in the countryside mansion, explaining, "this is where my mother always used to sit". Elise reminisced on her former life in Damascus,

"[p]eople here meet me as a refugee. In my country in Syria my husband and me, we are in a social club, and we are very well known there. Everybody knows us: 
the teachers know us, politicians know us, the doctors know us, the whole world knows us. The relations there are very well established, naturally. And here not... If you had been well known in all neighbourhoods and entertained social relations and you come here and no one wants to get to meet with you. Why? What is the matter with us? There is terrorism in our area ..."

Comparing her situation with her dependency on social welfare in Austria and the inability to ever rise to a higher social status due to her inability to join the workforce at her age, she claimed,

"[t]he amount is not enough for my husband and me to buy things in the house... Our social level in Syria was not quite good, it was really good. I don't want to live on the same level as a dog. If I have to live on the level of a dog, I will return to my country. Despite the circumstances, despite the war, I will go back to my country. The fear that I have is that the amount here is not enough for us. I am here now, me and my children."

Dequalification, the rupture of social relations, and public recognition seemed unbearable for many. What became apparent was that it was mainly elderly people or people who were in higher positions and had left their lifetime achievements suffered the most. Elise's then 72-year old husband decided some months after our interview to return to Damascus on his own, because he was not able to stay with his family in Austria under this precarious status.

In Austria, several long established Syrian and Arab associations, NGOs, and religious associations dedicated their efforts towards the socializing of newly arrived refugees and specifically the older generations. Interestingly, religious boundaries and ethnic affiliations play a lesser role in these clubs than the commonalities they share the fate of displacement, the loss of their way of life, the transnationalisation and fragmentation of families.

Many well-educated Syrians often have to work below their qualifications because of difficulties in getting their qualifications and previous work experience acknowledged. They can hardly build up similar social relations, a similar standard of living, a reputation and recognition. The recognition of diploma and experience often takes several years and, particularly, nostrification processes that include repeating some semesters at university in case of curriculum differences between Austria and Syria, include high financial costs.

In particular, people with higher education had problems translating their former job experience and studies into the Austrian context since for many comparable job positions (native) fluent German language skills was a precondition. For some, the loss of status was a very crucial experience - some of the persons interviewed had multiple experiences of loss and displacement, for example, some Palestinians who had managed a social upward mobility and had managed a successful living in Syria after decades. One person whose family had been displaced over generations was 51 year old Radwa, who used to work as a school headmaster. 
"In Syria, we were used to live in a certain way. We came here because of the war but we cannot work as cleaners or in the kitchen. It is true, these things had happened in our country, but it is not my fault and I should not be forced in this very low societal level. There is no shame in work but I mean, I was the director of a big school. Should I really work as a cleaning lady now?"

The danger of dequalification for people from abroad is not new. A 2006 study by Gudrun BIFFL and colleagues already showed that the number of migrants working in professions for which they are overqualified is twice as high as those of Austrians. BIFFL and colleagues see the reasons in the difficulties in the recognition of titles and competences, missing documents, language deficits, and the challenge to transfer knowledge. In addition, dequalification has a huge influence not only on the self-esteem of the person, and their capacities to withstand time - for example cost-intensive nostrification processes with an unpredictable outcome - paired with their own uncertainty about remaining in the country of residence.

The topic of changing family class positions through war shows how (forced) migration does not only change the legal and social status of an individual but reflects on family histories and their legacies, and creates a generational break with the future class position of the coming generations. Not being able to uphold the legacy of previous generations caused for some a feeling of duty of reparation towards their children and an increased interest in their upward social mobility.

\section{Future Orientation as Transgenerational Obligation}

For many, their own trajectory of "integration" was less a duty towards the state than an obligation to create chances for the children. Omayma and Radi, who were first hosted in a village in Lower Austria, where they managed to create some first friendships and could stay in a house with garden for free, left their home in Lower Austria and moved to Vienna so that their children would have better educational chances.

"In the village, there was nothing. No classes anymore for them. It was a small village. There was no institute. We wanted them to study and to have a future. They had a desire to study. They needed options",

explained Omayma. Radi had little hope of ever reaching the required level of German before reaching legal retirement age. What counted for him was his children's future, just as much as when the couple decided to leave Syria to safe their sons' lives.

"I am more optimistic for my children here. I hope that they work here and succeed with their life. I am hopeful for them, not for myself. I am already old. In a bit, I will die. Everyone dies at a point. We all go under the earth at a point. I just want that my children succeed. I am positive, because my children can find work here and they are in safety. I want my daughter to succeed and continue studying. She 
is a good nurse. I want her to find a good nurse. ${ }^{11}$ She can take care of people. I want her to have her own practice to help others. For example, she could also help elderly people. If she had a practice, I would want it to develop and become great. I want her to have a car."

The very strong support of the family for the education of younger ones often led to enormous expenses for others. Farid came to Austria with his sister's son and daughter, after having sent his wife and his own four children to Jordan. At the time of the interview, he still had not received an asylum decision and had been living for more than two years with his niece and nephew in a refugee shelter. Asylum seekers in Austria receive 180 Euros per month if they live in a self-catering accomodation. Farid's niece, who was an autodidact in German, was highly dedicated to continuing her education in Austria. Yet, since she had already reached legal age for compulsory education, she was not accepted to continue in an Austrian school. In order to meet the university admission criteria, Farid had no other choice than to send his niece to the private Libyan grammar school in Vienna, for 3000 Euros per school year, for which he had to take loans from friends and other relatives. In addition, Farid, who was not able to bring his wife and children from Jordan until his case was decided, sent almost all his money to support them in Jordan and invested in his children's education.

“... I am also responsible for my family in Jordan. The rent, that they have to pay, their studying fees, etc... I thought that my case would not take longer than six months. I had hoped that after six months, I would have found a place and I would have changed their (the family's) circumstances. But now, it is difficult. We need to pay for their living and the rent and so there and for the transportation and the teachers for the children ... My son is now in the age of his Matura, so he needs to take private lessons. He needs a tutor."

Farid, who described himself as a very social person, suffered not only from his legal uncertainty but also from his inability to fulfil his obligations to care for his sister's children and his own wife and children who were living on their own in Irbid.

"It changed from every side you can imagine. From the social side, it changed. I am a person who loves the life. I love to mingle with people. [silence] This is so hard here. I got depressed. A bit, not much. We live without knowing our destiny. We live for the unknown ... What is tomorrow? Of course, such words are not good. But it is like this: Today, I am here in Austria, but tomorrow? What is tomorrow? I do not know what will be. Concerning me, concerning the children, concerning everyone. This is not just me, all of us are concerned. I had my life established on a specific system. Work, study, house, belongings - everything is gone. A new society, new laws. This is not easy. In my age, this is not easy ... I changed. I changed my skin. When I left, I had 111 kilos. Today, my weight is 80 kilos. My hair changed from black to white ... I would say I have changed so much. It is the biggest change of my life. From the owner of a company to someone who does not know from

11 Daughter had worked as an anaesthesia-assistant nurse. 
where to get money. From someone who had ownerships to someone who lives in rent... I had my house, I had my car. Nowadays, I live without a house, without a car, without my children, without my family, without - Hard, hard. Psychologically, this is a huge psychological pressure. It is really a huge psychological pressure."

The setting Farid faces is like a protracted temporariness, "living in the space controlled by an Other” (Tize 2020, p. 14 in reference to Kublitz 2015), where he faces the obligations to solve the insecurity, economic deprivation, impoverishment, and educational needs his family members are in. His own unsolved asylum application reiterates the insecurity and his feelings of powerlessness. He mentions the impossibility of prospects to rebuild his family life anew. These post-migration stressors can worsen the physical and mental health of a person and enforce the experienced vulnerability and despair.

Hence, in the times of failure of international support for refugee families in Jordan, as well as the failure of the Austrian system to include highly skilled young refugees in grammar schools, it was Farid, father, husband, uncle, and brother, who tried to compensate the shortcomings of the systems. JOSEPH points to the paradox ofs "simultaneous intensified need for family-based relationality and destabilization of old patterns". In her research on post-war Lebanon, she concludes quite similar to Farid's experience that, "[t]he post-war ambiguities may lead to reinventing family and idiomatic kin relationships on new grounds and may permit constitution of new notions of personhood and citizenship for women and men from the bottom up. The cauldron of the Lebanese civil war has percolated these ideals to the surface” (2004, p. 276). Farid, after having sent his wife and children to the Jordanian border town Irbid, had planned to stay back in Deraa and take care of the family business. When the situation became too dangerous, his sister asked him to take her children and leave for Europe. Like for Farid, family ties were the most important reason why people left. In many cases, such as in Omayma's, Radwa's, but also in Elise's, it was to protect their adolescent sons from being drawn into the deadly war machinery. Yet, also the question whether to return to Syria after the war ends is also often influenced by concerns about children.

Despite knowing about his limited chances in the labour market and the difficult situation of his other family in Syria, including their eldest son, Radi was aware that any return would be difficult for their children.

"I wish that me and my children will find work and that we become parts of the society here. I hope my children find friends and have stable relationships with people here. I wish so. We will not return to our country, at least I do not expect to return. I do not think my children will go back home. If they go back home, they would not like it after the war and the destructions. I really wish them happiness if they decide to stay here. I wish that they integrate and become successful people. This is what I wish for."

Omayma was even clearer about how torn she was between wishing her children a successful future in Austria and returning to her other family in East-Ghouta. 
"Wallahi, ... we are here now. I stopped thinking about my future. My future is that my children study well."

Yet, already in the next sentence, Omayma suddenly corrected herself.

"I think about the future a lot. The future is for our children to learn and to become educated and succeed at the jobs that they are in. This is my future: only my children. [in low voice] and that I go back to my country. Yes, that I go back to the country. I hope I will be able to, one day. I wish, I wish, by God, to go to my country. As much as you like the country that you are in, your country of origin remains very special. I am longing for my country. Do you know this feeling? I am homesick. This is very hard. It is like the longing of a child for his mother. You miss, you miss your country. I really wish."

It was shown that the older generation is forced to define their aims in life anew and thus are highly supportive for planning the life of the next generation. It was mentioned by several of our interview partners that their main objective is the raising of the young generation. Inherent in this dynamic is that the next generation grows up with a lot of attention but also burdens, thus, to assert themselves and find their ways, and to fulfil the hopes and aims of the older generation. Various studies have analysed the intergenerational trauma in refugee families and herein the unconscious transmission of traumatic experiences to the next generation. Even if the next generation had not been exposed to violent experiences, their parents and grandparents may unintentionally their traumatic experiences to the upcoming generation, which reinforces vulnerability and can evoke psychiatric symptoms (see SANGalang \& VANG 2017). During the flight, the children's educational biographies were interrupted; access to education was often limited or they had to struggle with various curriculums in the transit countries (as e.g. Christophersen 2015 has shown for Jordan). Tize has shown in her study of Palestine refugees in Germany, who had only a toleration status over 16 years, that this permanent temporariness limited the capability of children. She pinpoints that children had to take over extra roles, as interpreters, as caring persons for younger siblings and (referring to SHAKAYA et al. 2014) this resulted in "a tenuous and ambivalent relationship between empowerment and vulnerability” (TIZE 2020, p. 15).

The FAMCORD study has also shown that the focus on the next generation (their education but also upholding their language competences, knowledge about the family's past and identity) is a coping mechanism, when people have lost the touch with their own way of life (WEINE et al. 2004, pp. $151 \mathrm{ff}$.). Living through the children, means the obligation of children to provide the elders with hope and family togetherness.

\section{The Shaping of "The Refugee Family" by The State}

Ambivalences, disjunctions and states of liminality are inherent in the experiences of refuge. Liminality is space and time related (SHAKYA 2014). Herein the policies of 
the nation states determine the length and modes of "liminal spaces", which is often related to a wider political system "that seek to control, contain, detain, and exclude them. Rather, what is needed is to transform these disjunct and liminal spaces that refugees occupy from sites of oppression and vulnerability to catalysts for creating more inclusive public policies related to immigration, resettlement, and citizenship” (SHAKYA 2014, p. 133). Among others, HeIDBRINK has shown how unaccompanied minors have to navigate in between, renegotiate and reformulate their family ties, as the U.S. immigration law refers to only the nuclear family and hinders a legal reunification beyond the nuclear family, which fosters clandestine migration and complex configurations within the families (see 2014, p. 137).

While research on forced migrants has long focused on either the collective or the individual experience, it has left the strong connection of refugees with family members and their responsibilities out of sight. Yet, recent research brought to awareness again how important it is to use a stronger systemic frame. For example, Kenan GüNGöR's research on identity and attitudes of young Afghan, Syrian, Chechen, Kurdish, Turkish and Bosnian teenagers in Austria shows the importance of the family in the acquisition of identity and ethnicity, gender roles, and religious worldviews (2019). Gabriele RASULY-PALECZEK, in her study on young unaccompanied minors from Afghanistan, scrutinizes how their obligations towards family in the various contexts of dispersion shape their decisions and motivations of flight (2017). Yet, while these studies discuss the influence of the broader family on the individual, this chapter has set out to show how the legal apparatus that regulates forced migrants' experience shapes families. The various empirical cases have shown, how important it is to set the family as the unit of analysis.

Family structures transform through forced migration. Through the multiple movements that forced migrants had experienced, many social relations have broken as a result. Not only Omayma had lost the close familiarity with her neighbourhood that mostly consisted of kin. MAKHLOUL and GHANEM's work on displaced families from Southern Lebanon on the Beirut margins, explains how multiple moves cause dissociations from kin networks, which in turn, cause the feeling that life is unfamiliar and unfamilial (2009).

As some of the empirical examples in our study, and other studies, comparatively discussed here have shown, war and refuge are not only causing the fragmentation of families but also foster a denuclearization, which as a result explains the intentions to maintain larger family relations despite distances. STAVER argues that families are very often not 'nuclear', as members of the families may be dead or lost. New relationships have been established during years of refuge and dwelling in transit countries, but in legal concerns only the families which existed before the refuge might be recognized in case of family reunification (STAVER 2008, p. 6). The legal considerations, on the contrary, are based on an ideal type of nuclear family without considering changes during displacement and refuge. The empirical examples have also shown that families try 
to uphold extended family relations, which become more and more transnational. The maintenance of these relations are attempts to uphold an economic and social security network as well as psychological support.

This chapter has also shown the various bureaucratic frameworks of refugee regimes that shape the configurations and meanings of family for forced migrants. The various legal regimes that govern forced migrants' lives in Austria and beyond, such as the Asylum Act or the Immigration Act, have strong influences on family relations and obligations. The European regulations on family reunion, the preconditions and the legal limitations of who this reunifiable family is, significantly affect the orientations towards and handling of family relations and thus the very meaning of "family". While mainly focusing on the relationship of the individual to the state, the effects of these legal regimes shape family lives, decisions, dynamics, and the very function of the family. The regulations evoke incredible dynamics in the family as a social institution and require a constant reinterpretation.

Totally ignored are the sources these family networks can provide for the individuals integration and wellbeing. On the contrary, these networks are seen as a threat, which would open possibilities to circumvent immigration restrictions, therefore "states have adopted the smallest and most restrictive definition of the family in family reunification cases as it allows them to restrict entry to the greatest possible extent” (STAVER 2008, p. 11). STAVER herein points to a contradiction in the policies of refugee regimes, as based on UNHCR reports "the family unit has a better chance of successfully... integrating in a new country rather than individual refugees” which would not only support the refugees aims but also the interests of the states (STAVER 2008, p. 28). Although formulated by STAVER in 2008, nothing seems to have changed in the last decade.

JoSEPH argues that states "invent" families in various ways as "social arrangements conducive to their governance" and hence attempt "to shape families to those social arrangements” (JOSEPH, 2018b, p. 9). Yet, this is not a historical particularity of the early $21^{\text {st }}$ century. According to her, there is a continuity in states' efforts "to shape family structure, authority within families, men's and women's roles, and control over children and youth through legislation and through political practices. States involved themselves in marriage, inheritance, and child custody laws and practices" (JosEPH, 2018 b, p. 8). Thus, it is these arrangements that ultimately affect "what counted as family and families and what 'families' could do throughout the centuries” (ibid.).

The presented cases have shown that the understandings of and relations to the "family" in its transnational realms strongly influences the social reality of the people involved. The time- space matrix in the de- and reterritorialisation processes intersects with the social obligations and expectations people have to fulfil. Although from a legal perspective, an individual who has gained asylum and a secure legal state in exile is then required to "integrate" themselves along the state prescriptions. These dense legal frameworks ultimately function in serving to protract the vulnerability and temporariness in family realms. 


\section{Bibliography}

AL-ALI, Nadje (2005), Reconstructing Gender: Iraqi women between dictatorship, war, sanctions and occupation. In: Third World Quarterly 26 (4-5), Special Issue, Reconstruction post Saddam Iraq: A Quixotic beginning to the Global Democratic Revolution. pp. 739-758. $<$ https://www.tandfonline.com/doi/abs/10.1080/01436590500128428>.

Al Jehani, Nour Al Malki (2018), Preface. In: Joseph S. (ed.), Arab family studies. Critical reviews. with a foreword by Noor Al Malki Al Jehani. First edition. Syracuse, New York, Syracuse University Press, xi.

Allan D. (2014), Refugees of the revolution: Experiences of Palestinian exile. Stanford University Press.

BALDASSAR L. et al. (2016), ICT-based co-presence in transnational families and communities: Challenging the premise of face-to-face proximity in sustaining relationships, Global Networks 12, pp. 133-144.

BIFFL G. et al. (2006). Erwerbstätigkeit und Arbeitslosigkeit: die Bedeutung von Einbürgerung, Herkunftsregion und Religionszugehörigkeit. In: Fassmann H. (ed.), 2. Österreichischer Migrations- und Integrationsbericht. 2001-2006, Klagenfurt, Drava Verlag, pp. 265-283.

BoIsSEvain J. (1979), Towards a social anthropology of the Mediterranean [and Comments and reply]. Current Anthropology 20(1), pp. 81-93.

Chakraborty R. (2019), Child, not Bride. Harvard International Review, 40(1), pp. 20-21.

Chatty D. (2018), Syria, In: Joseph S. (ed.), Arab family studies. Critical review; with a foreword by Noor Al Malki Al Jehani. First edition. Syracuse, New York, Syracuse University Press, pp. 233-246.

Christophersen M. (2015), Educating Syrian Youth in Jordan: Holistic Approaches to Emergency Response. Report Part Challenges Identified by Syrian Youth and Their Families. International Peace Institute. New York, Vienna, Manama.

DAvIs J. (1977), The people of the Mediterranean: an essay in comparative social anthropology. London, Routledge \& Keagan Paul.

Doumani B. ed. (2003), Family History in the Middle East: Household, Property, and Gender. Albany, State University of New York Press.

Duvignaud J. (1970), Change at Shebika: Report from a North African village. New York: Pantheon.

EAstmond M. (2012), Egalitarian Ambitions, Constructions of Difference: The Paradoxes of Refugee Integration in Sweden. In: Fog Olwig, K., Larsen B.R \& Rytter M. (eds.), Migration, Family and the Welfare State Integrating Migrants and Refugees in Scandinavia, London, New York, Routledge 2012, pp. 97-116.

Fog Olwig K. (2012), Integration: Migrants and Refugees between Scandinavian Welfare Societies and Family Relations. In: Fog Olwig, K., Larsen B.R \& Rytter M. (eds.), Migration, Family and the Welfare State Integrating Migrants and Refugees in Scandinavia, London, New York, Routledge, pp. 1-16.

Gebel M. \& Heyne S. (2017), Familienverständnis in Nordafrika und dem Nahen Osten. Analysen zu familiären Rollen und zur Abgrenzung vom Staat. Bamberg, University of Bamberg Press.

GrILlo R. (ed.) (2008), The Family in Question Immigrant and Ethnic Minorities in Multicultural Europe. IMISCOE Resarch. Amsterdam, Amsterdam University Press.

GüÇER M., Karaca S. \& DinçER B. (2013), Syrian Refugees. The Struggle For Life Between Boders. International Strategic Research Organization USAK. 
GÜNGÖR K. et al. (2019), Junge Menschen mit muslimischer Prägung in Wien: Zugehörigkeiten, Einstellungen und Abwertungen. ÖIF-Forschungsbericht, edited by Österreichischer Integrationsfonds. Wien.

Heidbrink L. (2014), Migrant Youth, Transnational Families, and the State: Care and Contested Interests, University of Pennsylvania Press.

International Rescue Committee (2012), Syrian Women \& Girls: Fleeing Death, Facing Ongoing Threats and Humiliation: A Gender-based Violence Rapid Assessment. <https:// data.unhcr.org/syrianrefugees/download.php?id $1 / 4900>$ [accessed 31 May 2020].

International Rescue Committee (2014), Are We Listening? Acting On Our Commitments to Women and Girls Affected by the Syrian Conflict. <https://www.rescue. org/sites/default/ files/resource-file/IRC_WomenInSyria_Report_WEB.pdf $>$ [accessed 31 May 2020].

IRAQ Body COUNT (no year), <https://www.iraqbodycount.org/>.

JOHNSON P. \& JOSEPH S. (2009), Introduction: War and transnational families. Journal of Middle East Women's Studies 5 (3), pp. 1-10. [DOI: 10.2979/mew.2009.5.3.1].

JoSEPH S. (1999), Intimate selving in Arab families: gender, self, and identity. Syracuse, New York, Syracuse University Press.

JosePH S. (2018a), Conclusions. Research on Arab Families Matters. In: JosePH S. (ed.): Arab family studies. Critical reviews; with a foreword by Noor Al Malki Al Jehani. First edition. Syracuse, New York, Syracuse University Press, pp. 482-494.

Joseph S. (2018b), Introduction. Family in the Arab Region: State of Scholarship. In: JosEPH S. (ed.): Arab family studies. Critical reviews; with a foreword by Noor Al Malki Al Jehani. First edition. Syracuse, New York, Syracuse University Press, pp. 1-14.

Joseph S. (ed.) (2018), Arab family studies. Critical reviews; with a foreword by Noor Al Malki Al Jehani. First edition. Syracuse, New York, Syracuse University Press.

Khater A. F. (2011), Inventing Home: Emigration, Gender, and the Middle Class in Lebanon, 1870-1920. Berkeley, University of California Press.

Kraler A. et al. (eds.) (2013), Gender, Generations and the Family in International Migration, IMISCOE Research, Amsterdam University Press.

Liamputtong P. (2007), Researching the Vulnerable. A Guide to Sensitive Research Methods. London Thousand Oaks, Sage.

Lindner C.B. (2018), Syrian Protestant Marriages in Early to mid-Nineteenth Century Bilād alShām: 'Aliens at Home' or rooted in Syrian Tradition, Journal of Mediterranean Studies 27 (2), pp. 133-148.

Lокот M. (2018), 'Blood Doesn't Become Water'? Syrian Social Relations during Displacement. Journal of Refugee Studies, fey059, pp. 1-22. Online version: >doi:10.1093/jrs/fey059>.

Makhoul J., Ghanem M. (2009), Displaced Arab families: mothers' voices on living and coping in postwar Beirut. Journal of Middle East Women's Studies 5 (3), pp. 54-73.

Mangrio E., Zdravkovic S. \& Carlson E. (2018), A qualitative study of refugee families' experiences of the escape and travel from Syria to Sweden BMC Res Notes 11, 594. $<\mathrm{https}: / /$ doi.org/10.1186/s13104-018-3702-1>.

MLodoch, K. (2015), The Limits of Trauma Discourse: Women Anfal Survivors in Kurdistan-Iraq (ZMO-Studien, 34) Berlin, Klaus Schwartz Verlag.

NABER, N. (2009), Transnational Families Under Siege. Journal of Middle East Women's Studies 5 (3), pp. 145-174. <DOI: 10.2979/mew.2009.5.3.145>.

Peers S. \& Rogers N. (eds.) (2006), EU Immigration and Asylum Law: Text and Commentary. Leiden, Boston, Martinus Nijhoff Publishers. 
Peteet J. (1997), Icons and Militants: Mothering in the Danger Zone, Signs 23 (1) (Autumn), pp. 103-29.

Pollard L. (2005), Nurturing the Nation: The Family Politics of Modernizing, Colonizing, and Liberating Egypt, 1805-1923. Berkeley, University of California Press.

Rasuly-PaleczeK G. (2017), Many Reasons for Leaving Afghanistan: Social Obligations in Times of Protracted Violence. In: Kohlbacher, J. \& Schiocchet, L. (eds.), From Destination to Integration - Afghan, Syrian and Iraqi Refugees in Vienna. ISR-Forschungsberichte 45. Vienna, Verlag ÖAW, pp. 57-83.

Rola Y. \& Moughalian C. (2016), Systemic violence against Syrian refugee women and the myth of effective intrapersonal interventions, Reproductive Health Matters, 24 (47), pp. $27-35$.

SANGalang C.C. \& VANG, C. (2017), Intergenerational Trauma in Refugee Families: A Systematic Review, Journal of Immigrant and Minority Health, 19(3), pp. 745-754. <DOI 10.1007/ s10903-016-0499-7>

Shakya Y.B. et al. (2014), Newcomer Refugee Youth as "Resettlement Champions" for Their Families: Vulnerability, Resilience and Empowerment, In: Simich L. \& Andermann L. (eds.), Refuge and Resilience: Promoting Resilience and Mental Health among Resettled Refugees and Forced Migrants, $7^{\text {th }}$ ed. New York, NY, Springer, pp. 131-154.

Statistik Austria (2020), Bevölkerung nach Staatsangehörigkeit und Geburtsland. <https:// www.statistik.at/web_de/statistiken/menschen_und_gesellschaft/bevoelkerung/bevoel kerungsstruktur/bevoelkerung_nach_staatsangehoerigkeit_geburtsland/index.html>.

Staver A. (2008), Family Reunification: A Right for Forced Migrants? Working Paper Series No. 51. Refugee Studies Centre. Oxford Department of International Development. University of Oxford.

TARaKi L. (Ed.) (2006), Living Palestine: Family Survival, Resistance, and Mobility Under Occupation. Syracuse, NY, Syracuse University Press.

TiRman J. (2011), The deaths of others: the fate of civilians in America's wars. Oxford University Press.

Titze C. (2019), Living in Permanent Temporariness: The Multigenerational Ordeal of Living under Germany's Toleration Status, Journal of Refugee Studies 2020 online version: <2019 - doi:10.1093/jrs/fez119>.

UNHCR (2014), Woman Alone: The Fight for Survival by Syria's Refugee Women. <http:// womanalone. unhcr.org/mobile/\#_ga $1 / 41.212173140 .1924729538 .1444225257>$ [accessed 31 May 2020].

UNHCR (2015), Family Reunification in Europe. Brussels 2015. <https://www.unhcr.org/56 fa38fb6.pdf>.

Veale A., Hijazi A., Osman Z. \& Macken S, (2019), Engaging Men to Support the Resilience of Syrian Refugee Children and Youth in Lebanon. In: BALvin N., \& Christie D.J. (eds.), Children and Peace. From Research to Action. Cham, Springer, pp. 25-43.

Weine S. et al. (2004), Family Consequences of Refugee Trauma. Family Process, 43(2), pp. 147-60.

WeIne S. et al. (2005), A mixed Methods Study of Refugee Families Engaging in Multiple-Family Groups. Family Relations, 54(4), pp. 558-568.

Young W.C. \& Shami S. (1997), Anthropological Approaches to the Arab Family: An Introduction, Journal of Comparative Family Studies 28(2), pp. 1-13. 